\title{
New Reference Values for Calcium
}

\author{
German Nutrition Society, Bonn, Germany
}

\section{Key Words}

Calcium · Nutrient intake $\cdot$ Reference value

\begin{abstract}
The nutrition societies of Germany, Austria and Switzerland are the joint editors of the 'reference values for nutrient intake'. They have revised the reference values for the intake of calcium and published them in June 2013. The reference values for the calcium intake for infants are derived from the calcium content of breast milk. For infants from 4 to $<12$ months of age, the calcium intake from solid foods is included in addition to the calcium intake from breast milk. Thus, the reference values for infants are estimated values; they are $220 \mathrm{mg} /$ day for infants to $<4$ months and $330 \mathrm{mg} /$ day for infants from 4 to $<12$ months of age. As a parameter for determining the calcium requirement in children and adolescents, calcium retention is taken into account. The average requirement is calculated by the factorial method. A balanced calcium metabolism is calculated based upon calcium balance studies and used as a parameter for the determination of the calcium requirement in adults. On the basis of the average requirement, recommended calcium intake levels for children, adolescents and adults are derived. Depending on age, the recommended calcium intake ranges between $600 \mathrm{mg} /$ day for children aged 1 to <4 years and 1,200 mg/ day for adolescents aged 13 to $<19$ years; for adults, it is $1,000 \mathrm{mg} /$ day.

(c) 2013 S. Karger AG, Basel
\end{abstract}

\begin{tabular}{ll}
\hline KARGER & $\begin{array}{l}\text { (c) 2013 S. Karger AG, Basel } \\
0250-6807 / 13 / 0633-0186 \$ 38.00 / 0\end{array}$ \\
$\begin{array}{l}\text { E-Mail karger@karger.com } \\
\text { www.karger.com/anm }\end{array}$ & $\begin{array}{l}\text { This is an Open Access article licensed under the terms of the } \\
\text { Creative Commons Attribution-NonCommercial 3.0 Un- } \\
\text { ported license (CC BY-NC) (www.karger.com/OA-license), } \\
\text { applicable to the online version of the article only. Distribu- } \\
\text { tion permitted for non-commercial purposes only. }\end{array}$
\end{tabular}

\section{Introduction}

The D-A-CH 'reference values for nutrient intake' are jointly issued by the nutrition societies of Germany, Austria and Switzerland [the abbreviation D-A-CH arises from the initial letters of the common country identification for the countries Germany (D), Austria (A) and Switzerland $(\mathrm{CH})][1]$. Currently, the 'reference values for nutrient intake' are being revised. Following vitamin D [2], calcium is the second nutrient that has been revised [1].

\section{Reference Values for the Intake of Calcium}

\section{Infants}

Breast milk is considered to be the optimal diet for infants $[3,4]$. Therefore, the reference value for the intake of calcium for infants is derived from the calcium content of breast milk.

A fully breastfed infant gets $220 \mathrm{mg}$ of calcium per day from drinking $750 \mathrm{ml}$ of breast milk $[5,6]$. At an absorption rate of $60 \%[7,8], 130 \mathrm{mg}$ of calcium is absorbed. In view of the fact that no calcium deficiency has been found

The German Nutrition Society initiated a working group for editing the reference values for calcium. The expert group consisted of H. Heseker, E. Leschik-Bonnet, J. Linseisen, H. Przyrembel, P. Stehle, D. Strohm, and A. Zittermann.
Dr. Daniela Strohm

Department of Science, German Nutrition Society (Deutsche Gesellschaft für Ernährung) Godesberger Allee 18

DE-53175 Bonn (Germany)

E-Mail strohm@dge.de 
in fully breastfed infants with a good vitamin D supply [9], the estimated value for calcium intake for breastfed infants at the age of $<4$ months is set to $220 \mathrm{mg}$ calcium (table 1 ).

Along with the introduction of solid foods, the daily calcium intake increases, and thus, calcium retention is higher as well [10]. The intake of calcium from solid foods is about $140 \mathrm{mg}$ per day [11]. An infant aged $4-12$ months drinks about $650 \mathrm{ml}$ per day [6]. Thus, the additional intake of calcium from breast milk is $190 \mathrm{mg}$ per day. Therefore, the estimated value for the calcium intake from breast milk and solid foods for infants at the age of 4 to $<12$ months is $330 \mathrm{mg}$ per day (table 1 ).

\section{Children}

Calcium retention is taken into account as a parameter for determining the calcium requirement in children and adolescents.

In the age group of the 1- to <4-year-olds, according to Lynch et al. [12], $140 \mathrm{mg}$ of calcium per day are retained for their growth needs. According to the calculation with the factorial method ${ }^{1}$ and a calculated absorption rate of $45.6 \%$, the average requirement for calcium is $474 \mathrm{mg} /$ day (table 2). To cover the requirement in $97.5 \%$ of this population group, $20 \%$ are added, which is about the 2-fold standard deviation. This procedure is also applied for the derivation of the reference values for the intake of calcium for all other age groups of children and adolescents. The calculation results in a recommended intake of $600 \mathrm{mg}$ calcium per day for 1 - to $<4$-year-old children (table 1).

Children aged 4 to $<7$ years retain about $120 \mathrm{mg}$ calcium per day [14]. According to the calculation with the factorial method and an assumed absorption rate of $38 \%$, the average requirement for calcium is $629 \mathrm{mg}$ /day (table 2). After adding $20 \%$, the recommended intake is set to $750 \mathrm{mg}$ calcium per day for 4 - to $<7$-year-old children (table 1).

Children aged 7 to $<10$ years may already be in the late prepubescent phase and have to retain about $140-160 \mathrm{mg}$ of calcium per day for optimal bone growth $[11,15,16]$. According to the calculation with the factorial method and an assumed absorption rate of $38 \%$, the average requirement for calcium is $776 \mathrm{mg}$ /day (table 2). After adding $20 \%$, the recommended intake is set to $900 \mathrm{mg}$ calcium per day for children of this age group (table 1).

\footnotetext{
${ }^{1}$ The factorial method calculates the sum of the estimated losses of calcium (through urine, sweat and endogenous fecal losses) and of the estimated or calculated calcium storage and adjusts for the respective calcium absorption rate to calculate the desirable calcium intake [13].
}

Table 1. Reference values for calcium intake (recommended intake) [1]

\begin{tabular}{lc}
\hline Age & Calcium, mg/day \\
\hline Infants & \\
0 to $<4$ months $^{\text {a }}$ & 220 \\
4 to $<12$ months & \\
Children & 330 \\
1 to $<4$ years & 600 \\
4 to $<7$ years & 750 \\
7 to $<10$ years & 900 \\
10 to $<13$ years & 1,100 \\
13 to $<15$ years & 1,200 \\
Adolescents and adults & \\
15 to $<19$ years & 1,200 \\
19 to $<65$ years & 1,000 \\
65 years and older & 1,000 \\
Pregnant women & 1,000 \\
Lactating women &
\end{tabular}

a Estimated value for breastfed infants. ${ }^{\mathrm{b}}$ Estimated value for the calcium intake from breast milk and solid foods. ${ }^{\mathrm{c}}$ Pregnant women $<19$ years old 1,200 mg. ${ }^{\mathrm{d}}$ Lactating women $<19$ years old $1,200 \mathrm{mg}$.

\section{Children from 10 Years of Age and Adolescents}

Vatanparast et al. [20] used data from 85 boys and 67 girls aged 9-18 years in Canada to determine their calcium requirement. Girls and boys aged 10 to $<13$ years retain 151 and $141 \mathrm{mg}$ calcium per day, respectively, according to Vatanparast et al. [20]. Because a higher absorption rate has to be expected during rapid growth than during slower growth $[23,24]$, and due to the earlier onset of the pubertal growth spurt in girls than in boys, in girls of this age group, an absorption rate of $42 \%$ is assumed. The absorption rate in boys of this age group is 38\% [19]. According to the calculation with the factorial method, the average requirement in girls and boys is about $900 \mathrm{mg}$ calcium per day (table 2). After adding $20 \%$, the recommended intake for girls and boys at the age of 10 to $<13$ years is $1,100 \mathrm{mg}$ calcium per day (table 1).

According to Vatanparast et al. [20], girls and boys at the age of 13 to $<19$ years retain 92 and $210 \mathrm{mg}$ calcium per day, respectively. Other studies also showed that calcium retention in boys aged $12-15$ years is higher than in girls of the same age at the same calcium intake [23,24]. The higher calcium retention in boys than in girls was attained through lower urinary excretion and a higher calcium absorption rate [24].

According to the calculations with the factorial method, a calculated absorption rate of 38\% in girls [19] and a 
Table 2. Calculation of the average calcium requirement in children and adolescents according to the factorial method

\begin{tabular}{|c|c|c|c|c|c|c|c|}
\hline Age, years/gender & $\begin{array}{l}\text { Average } \\
\text { calcium } \\
\text { accretion, } \\
\text { mg/day }\end{array}$ & $\begin{array}{l}\text { Urinary calcium } \\
\text { losses, mg/day }\end{array}$ & $\begin{array}{l}\text { Endogenous } \\
\text { fecal calcium } \\
\text { losses, mg/day }\end{array}$ & $\begin{array}{l}\text { Sweat calcium } \\
\text { losses, mg/day }\end{array}$ & $\begin{array}{l}\text { Total calcium } \\
\text { needed, mg/day } \\
\text { (sum of the figures } \\
\text { in columns } 1-4 \text { ) }\end{array}$ & $\begin{array}{l}\text { Calcium } \\
\text { absorption, } \\
\%\end{array}$ & $\begin{array}{l}\text { Average } \\
\text { calcium } \\
\text { requirement, } \\
\text { mg/day }\end{array}$ \\
\hline 1 to $<4$, male/female & $142^{\mathrm{a}}$ & $37^{\mathrm{b}}$ & $37^{\mathrm{c}}$ & - & 216 & $45.6^{\mathrm{a}}$ & 474 \\
\hline 4 to $<7$, male/female & $124^{\mathrm{d}}$ & $45^{\mathrm{b}}$ & $40^{c}$ & $30^{\mathrm{b}}$ & 239 & $38^{\mathrm{e}}$ & 629 \\
\hline 7 to $<10$, male/female & $150^{\mathrm{f}}$ & $55^{\mathrm{b}}$ & $50^{c}$ & $40^{\mathrm{b}}$ & 295 & $38^{\mathrm{e}}$ & 776 \\
\hline 13 to $<19$, female & $92^{\mathrm{g}}$ & $100^{\mathrm{h}}$ & $100^{\mathrm{i}}$ & $53^{j}$ & 345 & $38^{\mathrm{e}}$ & 908 \\
\hline 13 to $<19$, male & $210^{\mathrm{g}}$ & $75^{\mathrm{h}}$ & $100^{\mathrm{i}}$ & $55^{\mathrm{b}}$ & 440 & $42^{\mathrm{k}}$ & 1,048 \\
\hline
\end{tabular}

${ }^{\mathrm{a}}$ Lynch et al. [12]. ${ }^{\mathrm{b}}$ Weaver [17], adjusted to age where necessary. ${ }^{\mathrm{c}}$ Mean value from Weaver [17] and calculation according to Abrams et al. [18], adjusted to age where necessary. ${ }^{\mathrm{d}}$ Ames et al. [14]. ${ }^{\text {e }}$ An absorption rate of $38 \%$ is assumed based on Wastney et al. [19]. ${ }^{f}$ Assumption from Abrams et al. [15] and the Institute of Medicine [11] as well as from the fact that children in the late prepubescent phase have to retain a little more calcium per day for optimal bone growth than the next younger age group [16]. g Vatanparast et al. [20]. ${ }^{\mathrm{h}}$ Abrams et al. [21], adjusted to age where necessary. ${ }^{\mathrm{i}}$ Mean value from Weaver [17] and calculation according to Abrams et al. $[18,21]$, adjusted to age where necessary. ${ }^{j}$ Mean value from Weaver [17] and Palacios et al. [22]. ${ }^{\mathrm{k}}$ According to Jackman et al. [23] and Braun et al. [24], during the pubertal growth period, the rate of calcium absorption is increased at the same calcium intake; therefore, an absorption rate of $42 \%$ is assumed during rapid pubertal growth. higher assumed absorption rate of $42 \%$ in boys due to rapid pubertal growth, the average requirement in girls and boys is 908 and 1,048 mg/day, respectively (table 2). After adding $20 \%$, the recommended intake for girls and boys at the age of 13 to $<19$ years is $1,200 \mathrm{mg}$ calcium per day (table 1).

\section{Adults $<65$ Years of Age}

The point in life when peak bone mass is reached varies between different bones and joints and also between different individuals (at the end of adolescence or possibly only in the 3rd decade of life) [25-27]. According to Barger-Lux et al. [28], bone mass still increases by $0.28 \%$ per year in women at the age of 20-30 years. An intake of $>800 \mathrm{mg}$ calcium per day does not result in an additional increase in bone mass [29]. After reaching peak bone mass, an age-dependent annual loss of bone mass of about $1 \%$ occurs in both genders [30].

Bone is subject to constant formation and breakdown. To preserve bone mass, it is necessary to maintain both muscle mass and calcium balance. Calcium balance is taken into account as a parameter for deriving the calcium requirement in adults $<51$ years old. On the basis of calcium balance studies with a total of 73 women at the age of 20-75 years (mean age 47) and 82 men at the age of 19-64 years (mean age 28), Hunt and Johnson [31] determined that a mean calcium intake of $741 \mathrm{mg} /$ day at an average absorption of $25 \%$ is required for cal- cium balance, independent of age and gender. This corresponds to the average requirement. Considering the variation in the requirement in the population by adding $30 \%$, the recommended intake for adults $<65$ years is set to $1,000 \mathrm{mg}$ calcium per day (table 1 ).

Some observational studies showed a positive association between the intake of calcium and bone density in premenopausal women $[32,33]$. In these studies, physical activity was included as a factor influencing bone density. Data regarding vitamin D supply were not available, and therefore, the validity of the results is limited. In men, it was mainly not possible to confirm such an association [34-36].

The loss of bone mass, and hence a negative calcium balance, is associated with aging (especially with the loss of muscle mass with age) and occurs earlier and more abruptly in women than in men due to the menopause [37]. Adequate calcium intake can reduce the loss of bone mass but cannot prevent it [11]. A meta-analysis by Tang et al. [38] of 29 randomized controlled intervention studies in women at the age of 50-85 years showed a lower bone density loss at a calcium intake of $1,200 \mathrm{mg} /$ day compared with a lower calcium intake. However, this meta-analysis could not show any dose-response relationship, as in most of the studies, a calcium supplement of $1,200 \mathrm{mg} /$ day was administered, and the total intake of calcium (intake from foods and supplements) was not recorded. Furthermore, this meta-analysis included both 
studies that investigated calcium intake alone and studies that investigated calcium intake in combination with vitamin D. However, the individual studies with the administration of calcium alone also showed positive effects (reduced loss) on bone density.

Because there is no clear evidence that a calcium intake of more than 1,000 $\mathrm{mg}$ provides additional benefit regarding bone health in this age group, the recommended intake for women $>50$ years old is not higher than that either.

\section{Adults $>65$ Years of Age}

For the age group of 65 years and older, the risk of fracture is taken into account as a parameter to derive the reference value. The meta-analysis by Tang et al. [38] demonstrated a lower bone density loss and a reduced risk of fracture with a supplementation of $1,200 \mathrm{mg}$ calcium per day (in combination with vitamin D). A subsequent intervention study also showed that supplementation with $1,200 \mathrm{mg}$ calcium per day and an additional calcium intake of about $900 \mathrm{mg} /$ day from foods reduced the risk of fracture [39].

In contrast, other studies including a meta-analysis did not detect a preventive effect of a calcium intake of $>1,000$ $\mathrm{mg}$ /day regarding fractures [40-44].

The mentioned studies could not detect any doseresponse relationship between the calcium intake and the risk of fracture. There is no clear evidence that a calcium intake of $>1,000 \mathrm{mg}$ provides additional benefit regarding the bone health of adults $>65$ years old. Thus, to derive the reference value for adults $>65$ years of age, the derivation of the reference values for adults $<65$ years old is used, and the recommended intake for men and women $>65$ years old is set to $1,000 \mathrm{mg}$ calcium per day as well.

The reference values for the intake of calcium require a good vitamin D supply $[25(\mathrm{OH}) \mathrm{D}$ serum concentration of $\geq 50 \mathrm{nmol} / \mathrm{l}]$ in all age groups. Especially for the age group $>65$ years, it was shown that particularly the combination of a calcium intake corresponding to the recommended intake and a good vitamin D supply lowers the risk of fracture [45].

\section{Pregnancy and Lactation}

The fetal calcium requirement reaches its maximum during the $3 \mathrm{rd}$ trimester and is mainly covered by an increased rate of calcium absorption during pregnancy [46]. Calcium absorption doubles during pregnancy [4749]. In pregnant women, not only the intestinal calcium absorption is higher, but also the glomerular filtration rate of the kidneys and along with that, the renal calcium excretion is increased. During late pregnancy, bone resorption is also enhanced. These gestational changes are temporary adaptations that usually are not associated with an increased risk of osteoporosis [50,51].

In randomized controlled intervention studies, no benefit of an additional calcium intake which exceeded the recommended intake for non-pregnant adolescents and adults was detected [52]. According to these data, the requirement during pregnancy does not differ from the requirement in non-pregnant adolescents and adults, and therefore, the recommended intake for pregnant adolescents $<19$ years old is set to $1,200 \mathrm{mg}$ calcium per day and for pregnant women 19 years and older to $1,000 \mathrm{mg}$ calcium per day (table 1 ).

During lactation, the calcium for the infant's requirement is extracted from the mother's bones $[53,54]$. However, an increased calcium intake during lactation neither reduces calcium release from maternal bone [53, 55-58] nor influences breast milk calcium concentration [59]. Thus, the recommended calcium intake for breastfeeding women is the same as for other adolescents and adults. The recommended calcium intake for breastfeeding mothers $<19$ years old is $1,200 \mathrm{mg} /$ day and for breastfeeding mothers $>19$ years old is $1,000 \mathrm{mg} /$ day (table 1 ).

After weaning, the hormone-related (hypoestrogenemia) loss of bone density during lactation [60] is compensated with a calcium intake equal to the reference value $[54,61]$, so that breastfeeding is not associated with a higher risk of osteoporosis $[51,62,63]$.

\section{Ensuring a Sufficient Calcium Supply}

It is possible to ensure a sufficient supply of calcium with a high intake of foods with a naturally high calcium content. For a diet rich in calcium, especially milk and dairy products are recommended, not only because of their high calcium content and the quantity that is consumed, but also because of their absorption-promoting properties discussed in the literature. Mineral waters with a calcium content of $>150 \mathrm{mg}$ calcium per liter are also suitable. Due to their low energy density, various types of vegetables with a calcium content of $>80 \mathrm{mg}$ per $100 \mathrm{~g}$ are particularly suitable for a diet rich in calcium [5]. Broccoli in particular can contribute to a sufficient calcium supply because of its low oxalate content and possibly other absorption-promoting properties [84]. Calcium intake should be distributed among several meals throughout the day, because this increases the intestinal calcium absorption rate. 
Industrially manufactured infant milk has a higher calcium content than breast milk. In the European Union, the allowed range is between 33 and $91 \mathrm{mg}$ per $100 \mathrm{ml}$, with an energy value of $65 \mathrm{kcal}$ per $100 \mathrm{ml}$ of the infant milk [64]. This is accompanied by a lower calcium absorption rate from industrially manufactured infant milk than from breast milk [9]. However, due to the higher calcium content, a sufficient supply of calcium can be ensured in infants fed with infant milk formulas.

\section{Other Preventive Aspects}

In addition to the preventive effects of a good calcium supply on bone health that were taken into account to derive the reference values, other preventive aspects are dis- cussed. They are briefly described in the following by citing recent studies including meta-analysis, but without performing an evidence judgment based on a systematic literature research.

A high calcium intake (calcium from supplements and from dairy products) is associated with preventive effects regarding obesity $[65,66]$, hypertension $[67,68]$ and serum lipid concentrations [69-71] which in turn influence the risk of coronary heart disease. Due to the controversial results of the studies regarding the association between calcium supplementation and the risk of coronary heart disease [72-79], further research is needed [80-82].

The preventive effects of calcium on the risk of cancer are not fully understood either. In particular, an inverse association with the risk of colorectal cancer is discussed [83].

\section{References}

1 Deutsche Gesellschaft für Ernährung, Österreichische Gesellschaft für Ernährung, Schweizerische Gesellschaft für Ernährungsforschung, Schweizerische Vereinigung für Ernährung (eds): Referenzwerte für die Nährstoffzufuhr, ed 1, 5. Corrected Reprint. Neustadt a. d. Weinstrasse, Neuer Umschau Buchverlag, 2013.

2 German Nutrition Society: New reference values for vitamin D. Ann Nutr Metab 2012; 60:241-246.

3 Butte NF, Lopez-Alarcon MG, Garza C: Nutrient Adequacy of Exclusive Breastfeeding for the Term Infant during the First Six Months of Life. Geneva, WHO, 2002. http:// www.who.int/nutrition/publications/infantfeeding/nut_adequacy_of_exc_bfeeding_eng.pdf (accessed April 15, 2013).

$\checkmark 4$ American Academy of Pediatrics: Breastfeeding and the use of human milk. Pediatrics 2012;129:e827-e841

5 Souci SW, Fachmann W, Kraut H: Die Zusammensetzung der Lebensmittel. NährwertTabellen, ed 7. Stuttgart, Medpharm Scientific Publishers, 2008.

-6 Neville MC, Keller R, Seacat J, et al: Studies in human lactation: milk volumes in lactating women during the onset of lactation and full lactation. Am J Clin Nutr 1988;48:1375-1386.

7 Abrams SA, Wen J, Stuff JE: Absorption of calcium, zinc, and iron from breast milk by five- to seven-month-old infants. Pediatr Res 1997;41:384-390.

8 Fomon SJ, Nelson SE: Calcium, phosphorus, magnesium, and sulfur; in Fomon SJ (ed): Nutrition of Normal Infants, ed 1. St. Louis, Mosby, 1993, pp 192-218.
9 Abrams SA: Building bones in babies: can and should we exceed the human milk-fed infant's rate of bone calcium accretion? Nutr Rev 2006;64:487-494.

10 Abrams SA: Calcium absorption in infants and small children: methods of determination and recent findings. Nutrients 2010;2:474480.

11 Institute of Medicine: Dietary Reference Intakes for Calcium and Vitamin D. Washington, National Academies Press, 2011.

12 Lynch MF, Griffin IJ, Hawthorne KM, et al: Calcium balance in 1- to 4-year-old children. Am J Clin Nutr 2007;85:750-754.

13 Kuczmarski MF, Kuczmarski R: Nutrition monitoring in the United States; in Shils M, Shike M, Ross AC, Caballero B, Cousins RJ (eds): Modern Nutrition in Health and Disease, ed 10. Baltimore, Lippincott Williams \& Wilkins, 2006, pp 1687-1700.

14 Ames SK, Gorham BM, Abrams SA: Effects of high compared with low calcium intake on calcium absorption and incorporation of iron by red blood cells in small children. Am J Clin Nutr 1999;70:44-48.

15 Abrams SA, Copeland KC, Gunn SK, et al: Calcium absorption and kinetics are similar in 7- and 8-year-old Mexican-American and Caucasian girls despite hormonal differences. J Nutr 1999;129:666-671.

16 Ellis KJ, Shypailo RJ, Hergenroeder A, et al: Total body calcium and bone mineral content: comparison of dual-energy X-ray absorptiometry with neutron activation analysis. J Bone Miner Res 1996;11:843-848.

17 Weaver CM: Age related calcium requirements due to changes in absorption and utilization. J Nutr 1994;124(suppl 8):S1418-S1425.
18 Abrams SA, Sidbury JB, Muenzer J, et al: Stable isotopic measurement of endogenous fecal calcium excretion in children. J Pediatr Gastroenterol Nutr 1991;12:469-473.

19 Wastney ME, Ng J, Smith D, et al: Differences in calcium kinetics between adolescent girls and young women. Am J Physiol 1996;271: 208-216.

20 Vatanparast H, Bailey DA, Baxter-Jones AD, Whiting SJ: Calcium requirements for bone growth in Canadian boys and girls during adolescence. Br J Nutr 2010;103:575-580.

21 Abrams SA, Grusak MA, Stuff J, O’Brien KO: Calcium and magnesium balance in 9-14-yold children. Am J Clin Nutr 1997;66:11721177.

22 Palacios C, Wigertz K, Martin B, Weaver CM: Sweat mineral loss from whole body, patch and arm bag in white and black girls. Nutr Res 2003;23:401-411.

23 Jackman LA, Millane SS, Martin BR, et al: Calcium retention in relation to calcium intake and postmenarcheal age in adolescent females. Am J Clin Nutr 1997;66:327-333.

24 Braun M, Martin BR, Kern M, et al: Calcium retention in adolescent boys on a range of controlled calcium intakes. Am J Clin Nutr 2006;84:414-418.

25 Berger C, Goltzman D, Langsetmo L, et al: Peak bone mass from longitudinal data: implications for the prevalence, pathophysiology, and diagnosis of osteoporosis. J Bone Miner Res 2010;25:1948-1957.

26 Riggs BL, Melton LJ, Robb RA, et al: A population-based assessment of rates of bone loss at multiple skeletal sites: evidence for substantial trabecular bone loss in young adult women and men. J Bone Miner Res 2008;23:205-214. 
27 Tuck SP, Datta HK: Osteoporosis in the aging male: treatment options. Clin Interv Aging 2007;2:521-536.

-28 Barger-Lux MJ, Davies KM, Heaney RP: Calcium supplementation does not augment bone gain in young women consuming diets moderately low in calcium. J Nutr 2005; 135 : 2362-2366.

29 Weaver CM, Hill KM: Estimating calcium requirements; in Burckhardt $\mathrm{P}$, DawsonHughes B, Weaver C (eds): Nutritional Influences on Bone Health, ed 1. London, Springer, 2010, pp 41-50.

30 Jones G, Nguyen T, Sambrook P, et al: Progressive loss of bone in the femoral neck in elderly people: longitudinal findings from the Dubbo osteoporosis epidemiology study. BMJ 1994;309:691-695.

- 31 Hunt CD, Johnson LK: Calcium requirements: new estimations for men and women by cross-sectional statistical analyses of calcium balance data from metabolic studies. Am J Clin Nutr 2007;86:1054-1063.

- 32 Dionyssiotis Y, Paspati I, Trovas G, et al: Association of physical exercise and calcium intake with bone mass measured by quantitative ultrasound. BMC Womens Health 2010;10: 12.

33 Uusi-Rasi K, Sievänen $\mathrm{H}$, Pasanen $\mathrm{M}$, et al: Influence of calcium intake and physical activity on proximal femur bone mass and structure among pre- and postmenopausal women. A 10-year prospective study. Calcif Tissue Int 2008;82:171-181.

- 34 Atalar E, Aydin G, Keles I, et al: Factors affecting bone mineral density in men. Rheumatol Int 2009;29:1025-1030.

-35 Bischoff-Ferrari HA, Kiel DP, DawsonHughes B, et al: Dietary calcium and serum 25-hydroxyvitamin $\mathrm{D}$ status in relation to BMD among US adults. J Bone Miner Res 2009;24:935-942.

-36 Pettersson U, Nilsson M, Sundh V, et al: Physical activity is the strongest predictor of calcaneal peak bone mass in young Swedish men. Osteoporos Int 2010;21:447-455.

- 37 Ahlborg HG, Johnell O, Turner $\mathrm{CH}$, et al: Bone loss and bone size after menopause. N Engl J Med 2003;349:327-334.

-38 Tang BMP, Eslick GD, Nowson C, et al: Use of calcium or calcium in combination with vitamin D supplementation to prevent fractures and bone loss in people aged 50 years and older: a meta-analysis. Lancet 2007;370: 657-666.

-39 Bischoff-Ferrari HA, Rees JR, Grau MV, et al: Effect of calcium supplementation on fracture risk: a double-blind randomized controlled trial. Am J Clin Nutr 2008;87:19451951.

40 Peacock M, Liu G, Carey M, et al: Effect of calcium or $25 \mathrm{OH}$ vitamin D3 dietary supplementation on bone loss at the hip in men and women over the age of 60. J Clin Endocrinol Metab 2000;85:3011-3019.
41 Grant AM, Avenell A, Campbell MK, McDonald AM, MacLennan GS, McPherson GC, Anderson FH, Cooper C, Francis RM, Donaldson C, Gillespie WJ, Robinson CM, Torgerson DJ, Wallace WA, RECORD Trial Group: Oral vitamin D3 and calcium for secondary prevention of low-trauma fractures in elderly people (Randomised Evaluation of Calcium Or vitamin D, RECORD): a randomised placebo-controlled trial. Lancet 2005;365:1621-1628.

42 Prince RL, Devine A, Dhaliwal SS, Dick IM: Effects of calcium supplementation on clinical fracture and bone structure: results of a 5-year, double-blind, placebo-controlled trial in elderly women. Arch Intern Med 2006;166: 869-875.

43 Bischoff-Ferrari HA, Dawson-Hughes B, Baron JA, et al: Calcium intake and hip fracture risk in men and women: a meta-analysis of prospective cohort studies and randomized controlled trials. Am J Clin Nutr 2007;86: 1780-1790.

44 Warensjö E, Byberg L, Melhus H, et al: Dietary calcium intake and risk of fracture and osteoporosis: prospective longitudinal cohort study. BMJ 2011;342:d1473.

45 Linseisen J, Bechthold A, Bischoff-Ferrari HA, et al: Vitamin D und Prävention ausgewählter chronischer Krankheiten - Stellungnahme. Bonn, Deutsche Gesellschaft für Ernährung, 2011. http://www.dge.de/pdf/ws/ DGE-Stellungnahme-VitD-111220.pdf (accessed April 15, 2013).

46 Kovacs CS: Calcium and bone metabolism during pregnancy and lactation. J Mammary Gland Biol Neoplasia 2005;10:105-118.

-47 Heaney RP, Skillman TG: Calcium metabolism in normal human pregnancy. J Clin Endocrinol Metab 1971;33:661-670.

48 Kent GN, Price RI, Gutteridge DH, et al: The efficiency of intestinal calcium absorption is increased in late pregnancy but not in estab lished lactation. Calcif Tissue Int 1991;48: 293-295.

-49 O’Brien KO, Nathanson MS, Mancini J, Witter FR: Calcium absorption is significantly higher in adolescents during pregnancy than in the early postpartum period. Am J Clin Nutr 2003;78:1188-1193.

50 Prentice A: Maternal calcium metabolism and bone mineral status. Am J Clin Nutr 2000; 71:S1312-S1316.

51 Kovacs CS: Calcium and bone metabolism disorders during pregnancy and lactation. Endocrinol Metab Clin North Am 2011;40: 795-826.

52 Koo WW, Walters JC, Esterlitz J, et al: Maternal calcium supplementation and fetal bone mineralization. Obstet Gynecol 1999;94:577582.

53 Kalkwarf HJ, Specker BL, Bianchi DC, et al: The effect of calcium supplementation on bone density during lactation and after weaning. N Engl J Med 1997;337:523-528.
4 Kalkwarf HJ: Hormonal and dietary regulation of changes in bone density during lactation and after weaning in women. J Mammary Gland Biol Neoplasia 1999;4:319-329.

55 Cross NA, Hillman LS, Allen SH, et al: Calcium homeostasis and bone metabolism during pregnancy, lactation, and postweaning: a longitudinal study. Am J Clin Nutr 1995;61:514-523.

56 Fairweather-Tait S, Prentice A, Heumann KG et al: Effect of calcium supplements and stage of lactation on the calcium absorption efficiency of lactating women accustomed to low calcium intakes. Am J Clin Nutr 1995;62:1188-1192.

57 Prentice A, Jarjou LM, Cole TJ, et al: Calcium requirements of lactating Gambian mothers: effects of a calcium supplement on breastmilk calcium concentration, maternal bone mineral content, and urinary calcium excretion. Am J Clin Nutr 1995;62:58-67.

58 Laskey MA, Prentice A, Hanratty LA, et al: Bone changes after 3 months of lactation: influence of calcium intake, breast-milk output, and vitamin D-receptor genotype. Am J Clin Nutr 1998;67:685-692.

59 Jarjou LM, Prentice A, Sawo Y, et al: Randomized, placebo-controlled, calcium supplementation study in pregnant Gambian women: effects on breast-milk calcium concentrations and infant birth weight, growth, and bone mineral accretion in the first year of life. Am J Clin Nutr 2006;83:657-666.

60 Laskey MA, Price RI, Khoo BC, Prentice A: Proximal femur structural geometry changes during and following lactation. Bone 2011;48: 755-759.

61 Chantry CJ, Auinger P, Byrd RS: Lactation among adolescent mothers and subsequent bone mineral density. Arch Pediatr Adolesc Med 2004;158:650-656.

-62 Sowers M: Pregnancy and lactation as risk factors for subsequent bone loss and osteoporosis. J Bone Miner Res 1996;11:1052-1060.

63 Kovacs CS, Kronenberg HM: Maternal-fetal calcium and bone metabolism during pregnancy, puerperium, and lactation. Endocr Rev 1997;18:832-872.

64 EG-Richtlinie 2006/141/EG der Kommission vom 22. Dezember 2006 über Säuglingsanfangsnahrung und Folgenahrung und zur Änderung der Richtlinie 1999/21/EG. http:// eur-lex.europa.eu/LexUriServ/LexUriServ. do?uri=OJ:L:2006:401:0001:0033:DE:PDF (accessed April 15, 2013).

65 Lanou AJ, Barnard ND: Dairy and weight loss hypothesis: an evaluation of the clinical trials. Nutr Rev 2008;66:272-279.

-66 Shahar DR, Schwarzfuchs D, Fraser D, Vardi $\mathrm{H}$, Thiery J, Fiedler GM, Blüher M, Stumvoll M, Stampfer MJ, Shai I, DIRECT Group: Dairy calcium intake, serum vitamin $\mathrm{D}$, and successful weight loss. Am J Clin Nutr 2010; 92:1017-1022.

67 Dickinson HO, Nicolson DJ, Cook JV, et al: Calcium supplementation for the management of primary hypertension in adults. Cochrane Database Syst Rev 2006;19:CD004639. 
68 Wang L, Manson JE, Buring JE, et al: Dietary intake of dairy products, calcium, and vitamin $\mathrm{D}$ and the risk of hypertension in middle-aged and older women. Hypertension 2008; 51 : 1073-1079.

69 Bostick RM, Fosdick L, Grandits GA, et al: Effect of calcium supplementation on serum cholesterol and blood pressure. A randomized, double-blind, placebo-controlled, clinical trial. Arch Fam Med 2000;9:31-38.

70 Reid IR, Mason B, Horne A, et al: Effects of calcium supplementation on serum lipid concentrations in normal older women: a randomized controlled trial. Am J Med 2002;112: 343-347.

71 Reid IR, Ames R, Mason B, et al: Effects of calcium supplementation on lipids, blood pressure, and body composition in healthy older men: a randomized controlled trial. Am J Clin Nutr 2010;91:131-139.

72 Wang L, Manson JE, Song Y, Sesso HD: Systematic review: vitamin $\mathrm{D}$ and calcium supplementation in prevention of cardiovascular events. Ann Intern Med 2010;152:315323.

73 Bolland MJ, Grey A, Avenell A, et al: Calcium supplements with or without vitamin D and risk of cardiovascular events: reanalysis of the Women's Health Initiative limited access dataset and meta-analysis. BMJ 2011; 342:d2040.
74 Michaëlsson K, Melhus H, Warensjö Lemming E, et al: Long term calcium intake and rates of all cause and cardiovascular mortality: community based prospective longitudinal cohort study. BMJ 2013;346:f228.

75 Xiao Q, Murphy RA, Houston DK, et al: Dietary and supplemental calcium intake and cardiovascular disease mortality: the National Institutes of Health-AARP diet and health study. JAMA Intern Med 2013;173:639-646.

76 Bolland MJ, Barber PA, Doughty RN, et al: Vascular events in healthy older women receiving calcium supplementation: randomised controlled trial. BMJ 2008;336:262266.

7 Bolland MJ, Avenell A, Baron JA, et al: Effect of calcium supplements on risk of myocardial infarction and cardiovascular events: metaanalysis. BMJ 2010;341:c3691.

$\checkmark 78$ Lewis JR, Calver J, Zhu K, et al: Calcium supplementation and the risks of atherosclerotic vascular disease in older women: results of a 5-year RCT and a 4.5-year follow-up. J Bone Miner Res 2011;26:35-41.
79 Li K, Kaaks R, Linseisen J, Rohrmann S: Associations of dietary calcium intake and calcium supplementation with myocardial infarction and stroke risk and overall cardiovascular mortality in the Heidelberg cohort of the European Prospective Investigation into Cancer and Nutrition study (EPIC-Heidelberg). Heart 2012;98:920-925.

80 Body JJ, Bergmann P, Boonen S, et al: Extraskeletal benefits and risks of calcium, vitamin D and anti-osteoporosis medications. Osteoporos Int 2012;23(suppl 1):S1-S23.

81 Miller PD: Vitamin D, calcium, and cardiovascular mortality: a perspective from a plenary lecture given at the annual meeting of the American Association of Clinical Endocrinologists. Endocr Pract 2011;17:798-806.

82 Nordin BE, Lewis JR, Daly RM, et al: The calcium scare - what would Austin Bradford Hill have thought? Osteoporos Int 2011;22:30733077.

83 WCRF (World Cancer Research Fund)/AICR (American Institute for Cancer Research): WCRF/AICR Continuous Update Project report. Food, nutrition, physical activity, and the prevention of colorectal cancer. Washington, WCRF/AICR, 2011

84 Weaver CM, Proulx WR, Heaney R: Choices for achieving adequate dietary calcium with a vegetarian diet. Am J Clin Nutr 1999;70: S543-S548. 